\title{
Valuing Florida Water Resources: Summary by Regions ${ }^{1}$
}

\author{
Fei He, Tatiana Borisova, Xiang Bi, and Kelly Grogan²
}

\section{Introduction}

As a part of the EDIS series "Economic Value of Florida Water Resources," this publication aims to help the interested public learn about the economic benefits associated with local water resources. It presents examples of the economic benefits of water resources in five Florida regions, which are generally defined based on the Water Management Districts' boundaries (Figure 1).

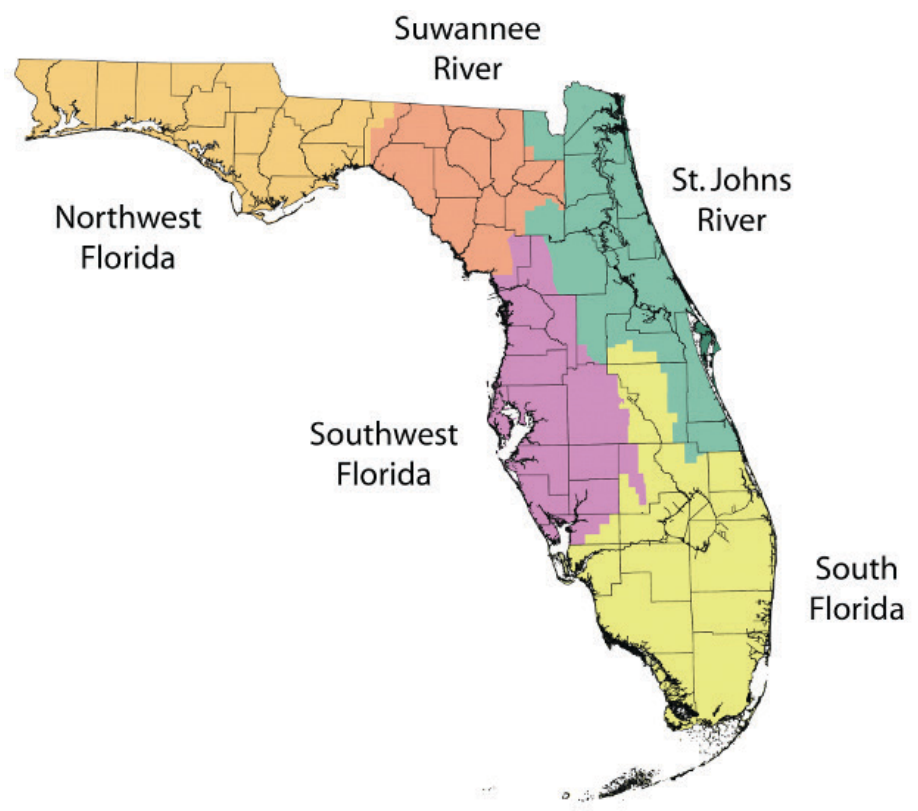

Figure 1. Florida Water Management Districts (FDEP 2017). Florida Water Management District boundaries.

Credits: Florida Department of Environmental Protection (FDEP), https://floridadep.gov/water-policy/content/water-managementdistrict\#SJR

\section{How can we measure the economic benefits provided by water resources?}

Economists use various approaches to estimate the benefits of natural resources. For example, consider state and national parks in Florida organized around springs, rivers, or coastal attractions. Tourists are drawn by water-based recreation opportunities, the chance to see manatees, or enjoy other activities directly or indirectly associated with water. These visitors spend money on lodging, meals, snacks, or diving equipment, thereby supporting local businesses. The studies that examine the visitor spending and the economic activities spurred by this spending are referred to as "the economic impact analyses." The Florida Department of Environmental Protection (FDEP) annually analyzes the state parks' visitation, visitor spending, and related economic contribution. The National Park Service also publishes analyses of economic contributions for the national parks. University of Florida's Economic Impact Analysis Program, as well as other Universities in the state, also examines economic contributions of visitor expenditures.

Another method to gauge the value assigned to water-related experiences is to ask visitors about their willingness to pay for various recreational experiences above their actual spending. Such an approach allows estimation of the values derived by visitors that are not captured in market transactions (referred to as "consumer surplus). Alternatively, this

1. This document is FE1100, one of a series of the Food and Resource Economics Department, UF/IFAS Extension. Original publication date July 2021. Visit the EDIS website at https://edis.ifas.ufl.edu for the currently supported version of this publication.

2. Fei He, Ph.D. student; Tatiana Borisova, associate professor and Extension specialist; Xiang Bi, former assistant professor; and Kelly Grogan, associate professor, Food and Resource Economics Department, University of Florida.

The Institute of Food and Agricultural Sciences (IFAS) is an Equal Opportunity Institution authorized to provide research, educational information and other services

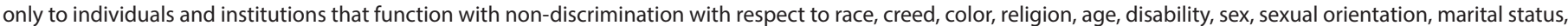

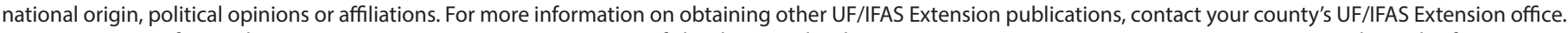
U.S. Department of Agriculture, UF/IFAS Extension Service, University of Florida, IFAS, Florida A \& M University Cooperative Extension Program, and Boards of County Commissioners Cooperating. Nick T. Place, dean for UF/IFAS Extension. 
value can be examined by looking at how far tourists travel for recreational activities. One can also assess the benefits of water quality improvements by considering riverfront house sale prices during periods with "good" or "bad" river water quality. These and other methods to valuing the benefits provided by water resources are described in the overview publication in this series, here.

\section{Studies report different estimates for the same site. Can I add up these estimates?}

Sometimes the same recreational site or the same water body is examined repeatedly, frequently because of high regional or national significance. Economists can employ different valuation methods, focus on different types of benefits (e.g., recreation vs. riverfront property amenities), and employ various metrics (e.g., total recreational visitor spending $v s$. spending by non-local visitors only). To avoid possible double counting of the benefits, it is generally recommended to refrain from adding up different values estimated for the same site (even though there are exceptions to this general rule).

\section{Northwest Florida: State Parks and Visitors' Spring-Based Recreation}

The Florida Panhandle (Figure 2) is recognized for its freshwater springs and rivers. Both coastal and inland state and national parks contribute significantly to the regional economy (Table 1). For example, the estimated economic contribution for Edward Ball Wakulla Springs State Park was $\$ 19.7$ million in 2019, supporting 276 full- and parttime jobs.

Further, the value of recreational experiences to the visitors was estimated for recreation on Edward Ball Wakulla Springs State Park, Jackson Blue Springs County Recreation Area, and sites in the Apalachicola River Basin (Table 2). For example, cave diving trips to the Jackson Blue Springs County Recreation Area are valued by the visitors at $\$ 155$ per person per trip (above the actual trip expenditures). These estimates illustrate the importance of protecting local water resources.

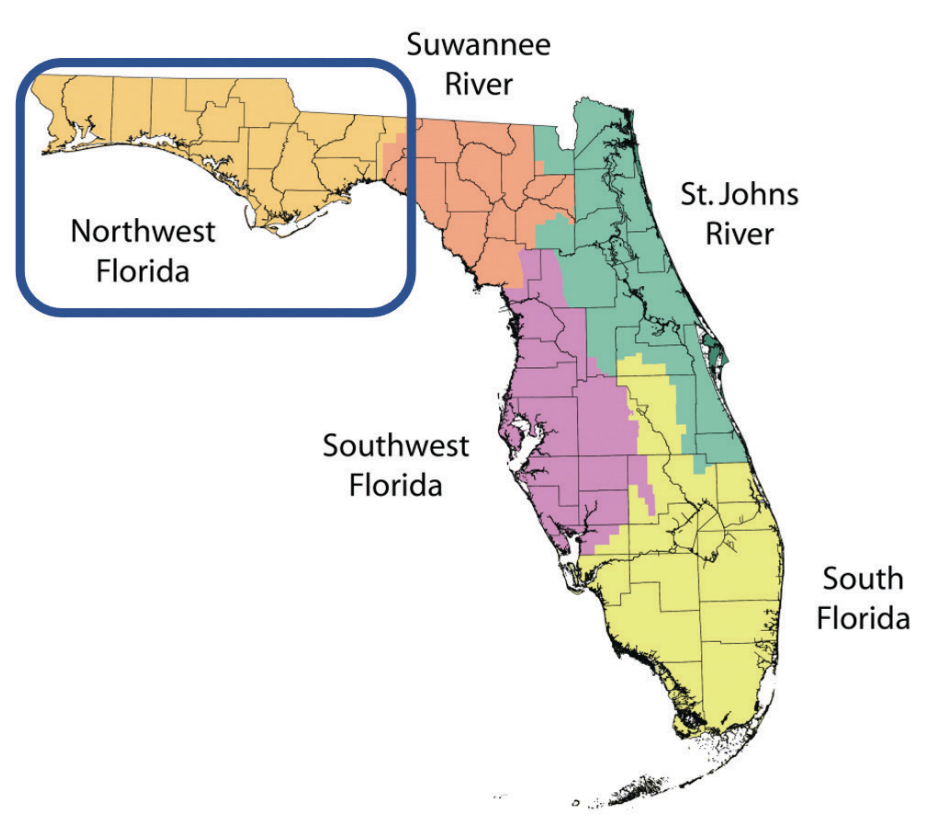

Figure 2. Northwest Florida Water Management District (NWFWMD). Credits: Based on FDEP 2017

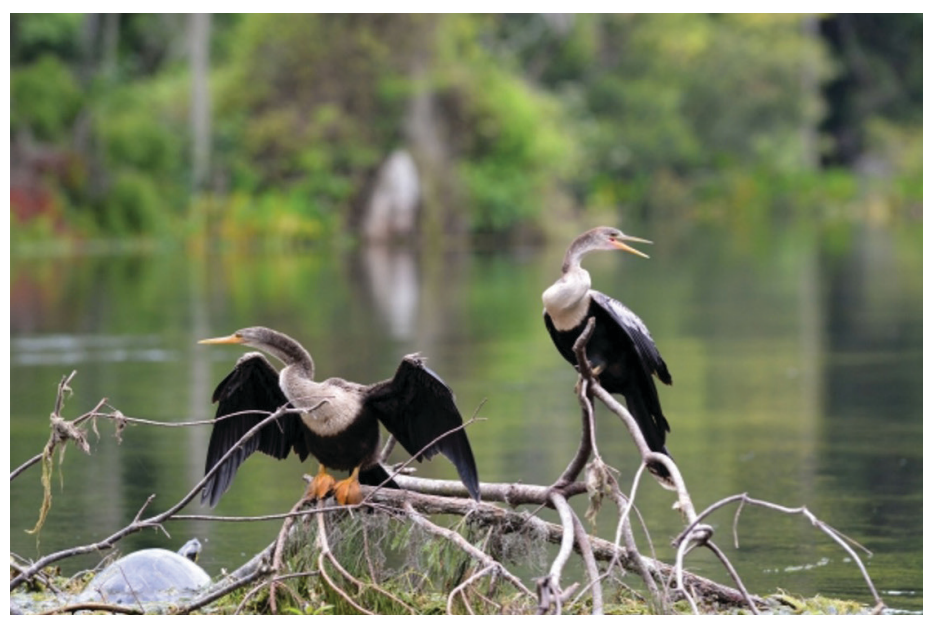

Figure 3. Edward Ball Wakulla Springs State Park Credits: NWFWMD

\section{Suwannee River Basin: Florida's Springs Region}

Springs are unique natural landmarks in north Florida, attracting many recreational visitors and supporting local economies. The Suwannee River Water Management District (Figure 4) has one of the highest concentrations of large freshwater springs in the United States (SRWMD undated). These large springs are referred to as first- and second-magnitude springs for the large volumes of water they discharge-more than ten or even 100 cubic feet per second. For example, Figure 5 shows Blue Hole at Ichetucknee Springs, one of Florida's large springs, located in the District. Spring recreational and wildlife depend on the water flow and good water quality, and stakeholder groups and agencies are working on restoring or protecting this 
unique natural resource. Reduction in spring water quality and flow is a concern for many.

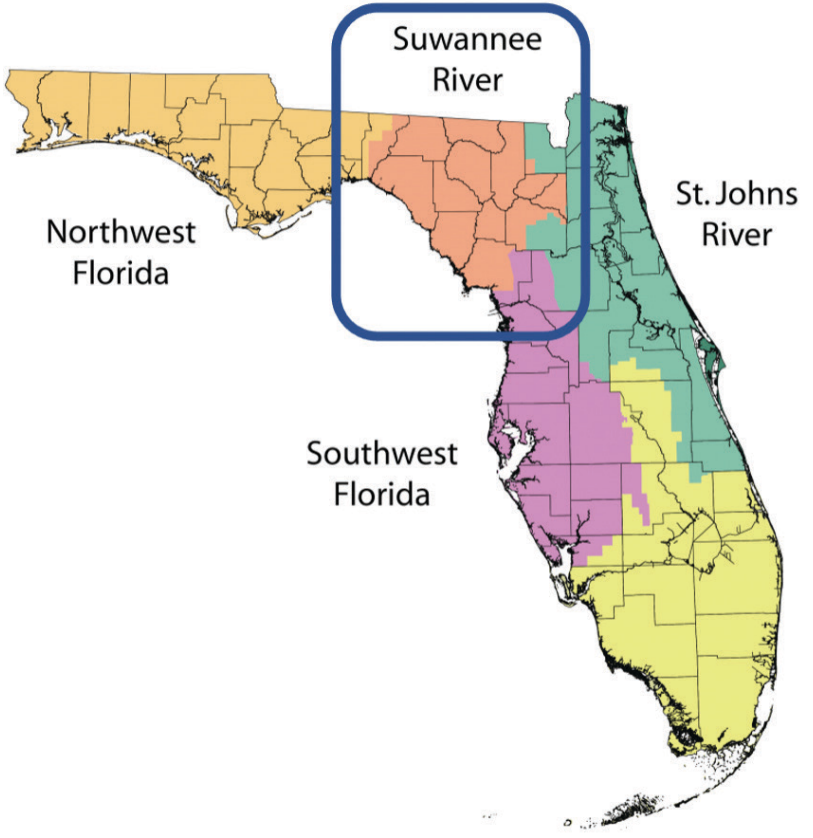

South Florida

Figure 4. Suwannee River Water Management District (SWFWMD). Credits: Based on FDEP 2017

Several studies estimated the spending of visitors to the springs and related this spending to regional economic activities. For example, 258,000 people attended Ichetucknee Springs State Park in 2019, contributing \$21.7 million to the regional economy, and supporting 304 jobs (Table 3).

In addition, Wu et al. (2018) examined the visitors' willingness to pay for their recreational experiences in addition to the expenses incurred. For example, for Ichetucknee Springs, Wu et al. (2018) estimated that the value of the visitors' recreational experiences was $\$ 14.66$ million above the actual trip expenditures (Table 4 ).

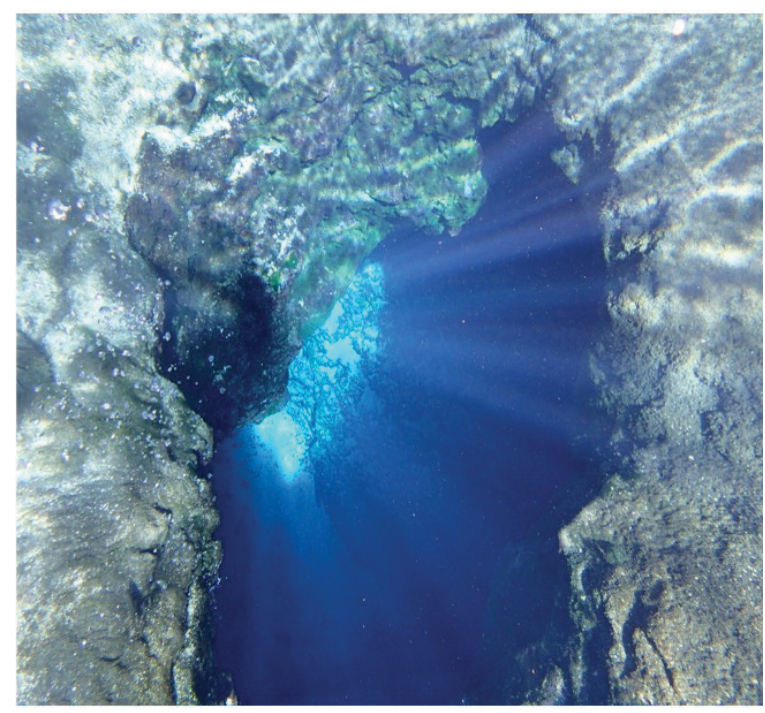

Figure 5. Ichetucknee Springs

Credits: Tyler Jones, UF/IFAS
Overall, these studies imply that deteriorating quality and reducing flows of the springs may result in a significant reduction in springs-related expenditures and thereby economic activity in the region and the loss of recreational opportunities and related benefits highly valued by the visitors.

\section{East Florida: Diverse Water Resources and Related Benefits}

Diverse water resources in east Florida, broadly defined as the area of St. Johns River Water Management District (SJRWMD, see Figure 6), provide residents and visitors with various recreational opportunities (Figure 7), waterfront amenities, and other benefits. The studies focusing on the economic impact of recreational benefits specifically are summarized in Table 5. For example, Blue Spring State Park was visited by more than 560,000 visitors in 2019, contributing almost $\$ 49$ million to the regional economy, and supporting 572 full-time and part-time jobs. In addition to the actual expenditure for the recreational trips (and related contribution to state economy), the value derived by the visitors to all inland water recreation sites in the region was estimated at \$208.9 million per year (Table 6).

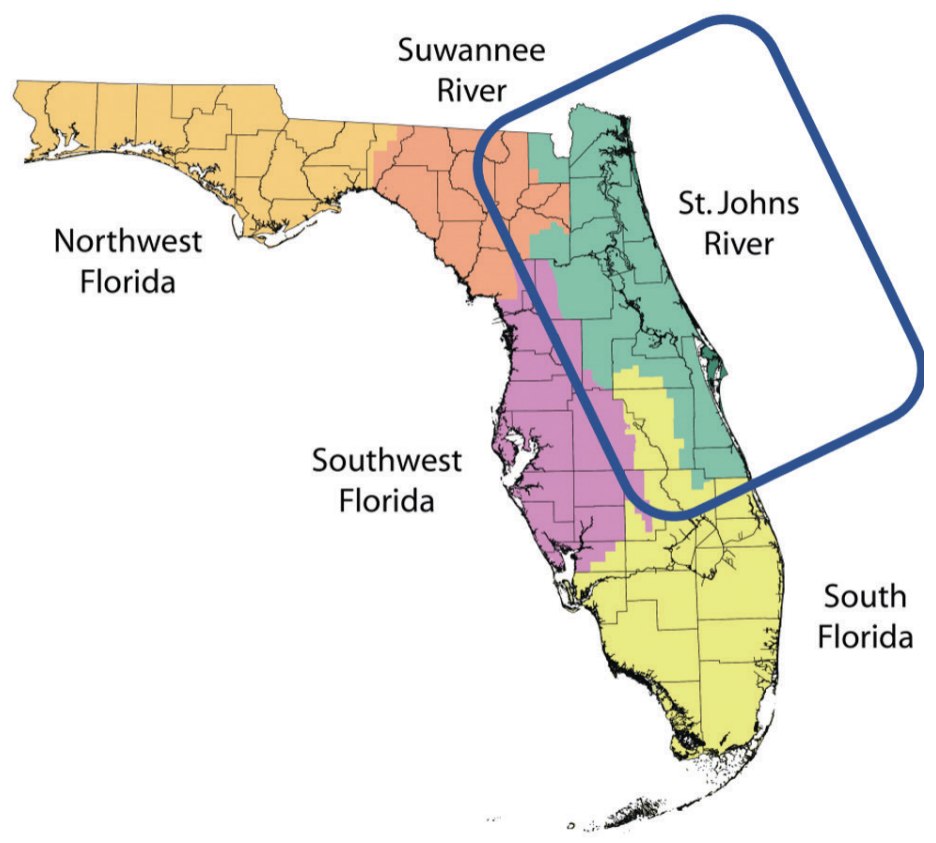

Figure 6. St. Johns River Water Management District (SJFWMD) Credits: Based on FDEP 2017

One of the largest cities in Florida and the United States, Jacksonville, is located in SJRWMD. It is not surprising that several economic studies conducted in this region focused on the value of clean water to residential households in Jacksonville and the surrounding area. Studies showed that improving river or lake water quality increases waterfront 
homes' prices, reflecting the worth of the enhanced amenity benefits provided by the water bodies (Table 7). Two other studies found that households are willing to pay for improved water quality for domestic use (Table 8). Overall, protecting and improving water quality and availability in rivers, lakes, and aquifers ultimately impacts locals' and visitors' well-being.

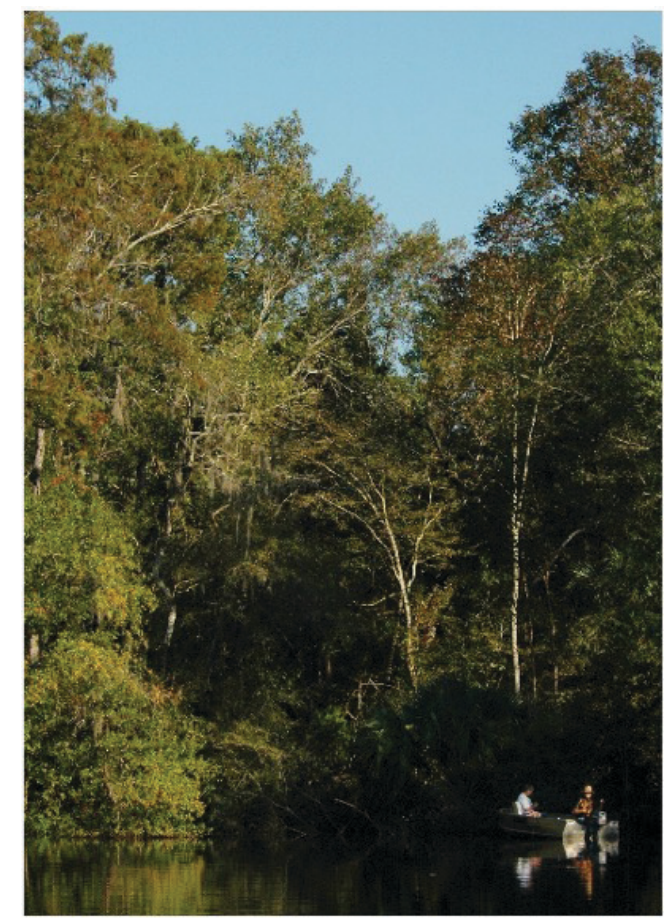

Figure 7. Two men fishing in the St. Johns River.

Credits: UF/IFAS

\section{West-Central Florida: Visitation of Coastal and Inland State Parks}

Inland springs and coastal areas in southwest Florida (Figure 9) attract many visitors annually, and visitors' spending is an important contributor to the region's economy. For example, more than 350 million people visited Rainbow Springs State Park in 2019, contributing \$31.1 million to the economy and supporting 436 full- and part-time jobs (Table 9). Deterioration of water resources can result in a significant reduction in recreational activity and related economic contributions in the region. More studies are underway to measure these impacts. For example, in 2020, the National Center for Coastal Ocean Science awarded a grant to study the economic impacts of the historic harmful algal bloom (commonly referred to as "red tide") in 2017-2019. Economists from major Florida universities lead the study, and study results should become available soon (NCCOS 2020a, NCCOS 2020b).

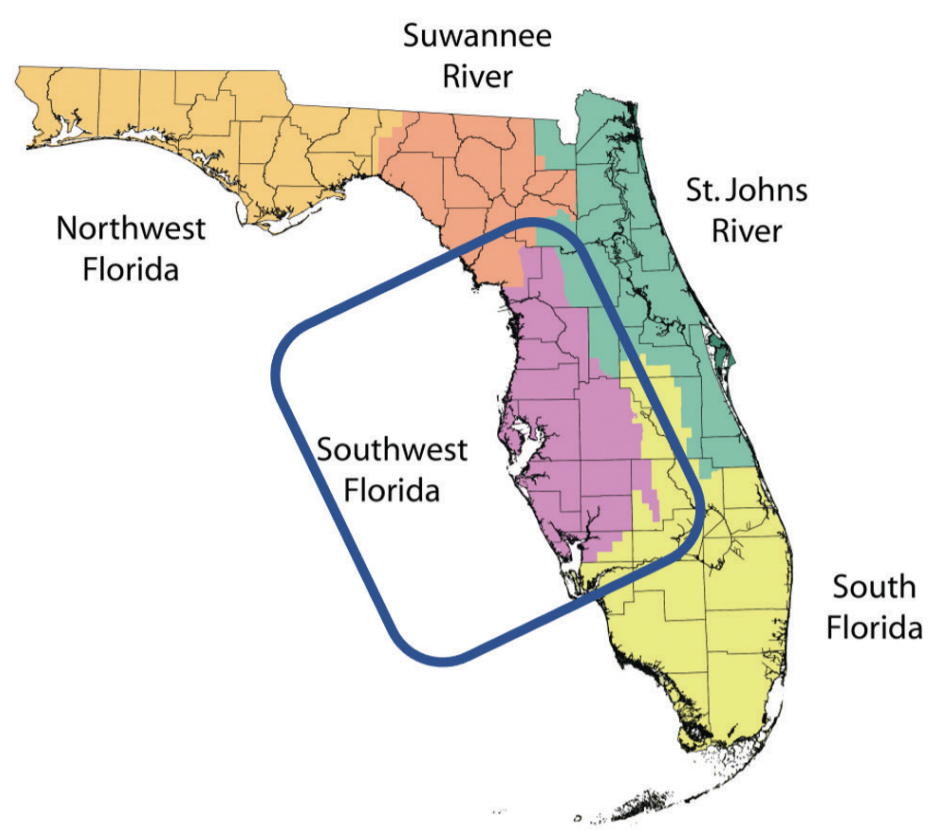

Figure 8. Southwest Florida Water Management District (SWFWMD). Credits: Based on FDEP 2017



Figure 9. South Florida Water Management District (SFWMD). Credits: Based on FDEP 2017

\section{South Florida: The Everglades and Other State and National Parks}

Wise management of water resources is crucial for the south Florida region (Figure 10). The studies conducted in the region focused on the following types of important "services" provided by natural resource sites: (a) recreation (with visitors' spending contributing to the regional economy, Table 10); (b) amenity provided by the waterfront properties, with the amenity impacted by river and estuary water quality changes (Table 11); and (c) variety of services 
provided by the Everglades, such as wildlife habitat and ecosystem function support (Table 12).

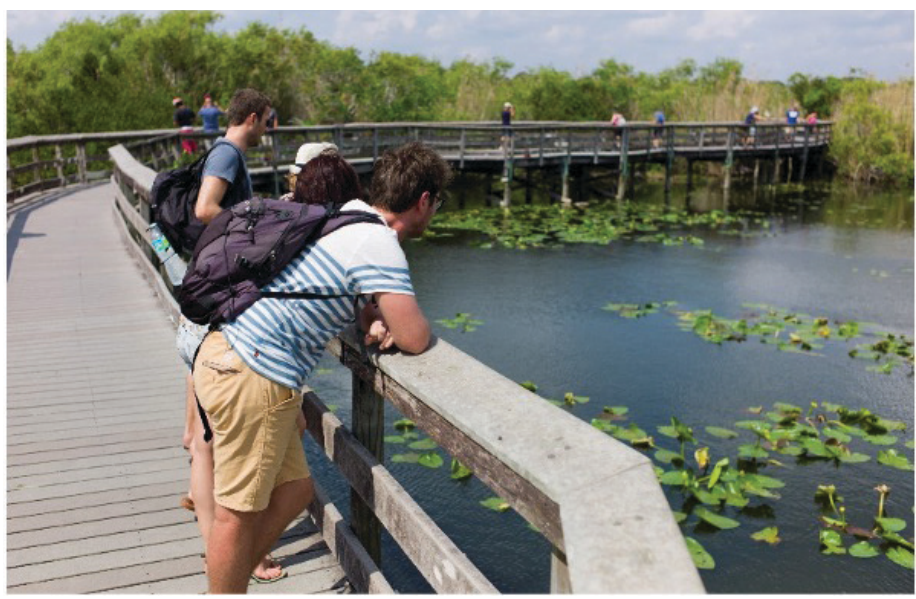

Figure 10. Tourists on a boardwalk at Everglades National Park. Credits: UF/IFAS

State parks and national preserves attract millions of people annually, and this visitation is essential for local business activities. Water quality in coastal waters can also significantly impact beachfront properties' attractiveness (and related tax collections). Preservation of wildlife habitat, water flow regulation, carbon sequestration, and other benefits provided by south Florida wetlands are also valued by many. Changes in these services will have an indirect but possibly significant influence on people's well-being. Future studies will provide additional estimates in support of this statement. For example, in 2020, the National Center for Coastal Ocean Science awarded a grant to study the economic impacts of the historic harmful algal bloom (commonly referred to as "red tide") in 2017-2019. Economists from major Florida universities lead the study, and study results should become available soon (NCCOS 2020a, NCCOS 2020b).

\section{Acknowledgements}

The authors acknowledge funding for the project "Water resources and human society: educating Floridians about the value of water resources" from UF Thompson Earth Systems Institute (TESI): Earth Systems Grants. TESI aims to support projects by UF students and postdoctoral scholars that communicate Earth systems research to the institute's audiences. See more at: TESI, https://www. floridamuseum.ufl.edu/earth-systems/blog/announcingthe-2018-ties-grant-recipients/. This work is also partially funded by USDA NIFA National Integrated Water Quality Program Award No. 2014-51130-22495 (PI: Kelly Grogan).

\section{References}

Alongi, D. 2012. "Carbon Sequestration in Mangrove Forests." Carbon Manage 3:313-322.

Alavalapati, J. R. R., R. K. Shrestha, G. A. Stainback, and J. R. Matta. 2004. "Agroforestry Development: An Environmental Economic Perspective." Agroforestry Systems 61:299-310.

Bin, O., and J. Czajkowski. 2013. "The Impact of Technical and Non-Technical Measures of Water Quality on Coastal Waterfront Property Values in South Florida." Marine Resource Economics 28 (1): 43-63.

Bin, O., J. Czajkowski, J. Li, and G. Villarini. 2017. "Housing Market Fluctuations and the Implicit Price of Water Quality: Empirical Evidence from a South Florida Housing Market." Environment \& Resource Economics 68 (2): 319-341.

Borisova, T., A. Hodges, and T. Stevens. 2015. Economic Contributions and Ecosystem Services of Springs in the Lower Suwannee and Santa Fe River Basins of North-Central Florida. https://fred.ifas.ufl.edu/pdf/economic-impactanalysis/FE958.pdf

Chaikaew, P., A. Hodges, and S. Grunwald. 2017. "Estimating the Value of Ecosystem Services in a Mixed-Use Watershed: A Choice Experiment Approach." Ecosystem Services 23:228-237.

Chatterjee, C., R. Triplett, C. K. Johnson, and P. Ahmed. 2017. "Willingness to Pay for Safe Drinking Water: A Contingent Valuation Study in Jacksonville, FL." Journal of Environmental Management 203: 413-421.

East Central Florida Regional Planning Council and Treasure Coast Regional Planning Council (ECFRPC and TCRPC). 2016. Indian River Lagoon Economic Valuation Update. https://loveourlagoon.com/IRL-EconomicValuation-Update-07252016.pdf

Ehrlich, O., X. Bi, T. Borisova, and S. Larkin. 2016. A Latent Class Analysis of Public Attitudes toward Water Resources with Implications for Recreational Demand. Retrieved from https://ageconsearch.umn.edu/bitstream/235853/2/ sjr_latentclass_submit_2_red.pdf

Florida Department of Environmental Protection (FDEP). 2018. Florida Park Service State Parks Map. https://www. floridastateparks.org/statewide-map 
Florida Department of Environmental Protection (FDEP). 2017. Water Management Districts. https:// floridadep.gov/water-policy/water-policy/content/ water-management-districts

Florida Department of Environmental Protection (FDEP). 2020. Economic Impact Assessment - Florida State Park System. https://floridadep.gov/sites/default/files/2019-2020\%20 EIA\%20Report\%20FINAL\%20and\%20COVER\%20MEMO. pdf

Guignet, D., P. J. Walsh, and R. Northcutt. 2016. "Impacts of Ground Water Contamination on Property Values: Agricultural Run-off and Private Wells." Agricultural and Resource Economics Review 45 (2): 293-318.

Huth, W. L., and O.A. Morgan. 2011. "Measuring the Willingness to Pay for Cave Diving." Marine Resource Economics 26:151-166. http://www.agnesmilowka.com/ ag_media/coverage/agecon-06-morgan-c.pdf

Milon, J. W., and D. Scrogin. 2006. "Latent Preferences and Valuation of Wetland Ecosystem Restoration.” Ecological Economics 56 (2): 162-175. http://www.sciencedirect.com/ science/article/pii/S0921800905000571

Morgan A.O. and W.L. Huth. 2011. Using revealed and stated preference data to estimate the scope and access benefits associated with cave diving. Resource and Energy Economics 33:107-118.http://www.sciencedirect.com/ science/article/pii/S0928765510000072

National Center for Coastal Ocean Science (NCCOS). 2020a. Assessment of the Short- and Long-Term Socioeconomic Impacts of Florida's 2017-2019 Red Tide Event. https://coastalscience.noaa.gov/project/assessment-of-theshort-and-long-term-socioeconomic-impacts-of-floridas2017-2019-red-tide-event/

National Center for Coastal Ocean Science (NCCOS). 2020b. Estimating Economic Losses and Impacts of Florida Red Tide. https://coastalscience.noaa.gov/project/estimating-economic-losses-and-impacts-of-florida-red-tide/

National Park Services. 2020. Visitor Spending Effects Economic Contributions of National Park Visitor Spending. https://www.nps.gov/orgs/1207/06-11-20-nps-visitorspending-generates-economic-impact-of-more-than41-billion.htm
Suwannee River Water Management District (SRWMD). Undated. Springs. https://www.mysuwanneeriver.com/267/ Springs

Seidel, V., W. Milon, A. Baker, and C. Diamond. 2015. Economic Impact of the St. Johns Water Quality on Property Values. In: Hacner, C.T (ed). Sr. Johns River Economic Study. Report submitted to the St. Johns River Water Management District under contract\#27884.

Shrestha, R. K., T. V. Stein, and J. Clark. 2007. "Valuing Nature-Based Recreation in Public Natural Areas of the Apalachicola River Region, Florida." Journal of Environmental Management 85: 977-985.

Wu, Q., X. Bi, K. Grogan, and T. Borisova. 2018. "Valuing Recreation Benefits of Natural Springs in Florida." Water 10 (10): 1379. https://www.mdpi.com/2073-4441/10/10/1379 
Table 1. Economic studies examining recreational benefits provided by water resources in the NWFWMD.

\begin{tabular}{|c|c|c|c|c|c|}
\hline Natural resource site and recreation type & County & $\begin{array}{c}\text { Annual } \\
\text { attendance }\end{array}$ & $\begin{array}{c}\text { Economic impact } \\
\text { indicator }\end{array}$ & $\begin{array}{l}\text { Total jobs } \\
\text { supported }\end{array}$ & Reference \\
\hline \multicolumn{6}{|c|}{ Contribution to the regional economy for selected state and national parks } \\
\hline \multicolumn{6}{|l|}{ National Park (2019 data) } \\
\hline Gulf Islands National Seashore & Santa Rosa & 5.6 million & $\begin{array}{l}\$ 310 \text { million total } \\
\text { economic output }\end{array}$ & $3,305^{\mathrm{a}}$ & $\begin{array}{l}\text { National } \\
\text { Park Services } \\
(2020)\end{array}$ \\
\hline \multicolumn{6}{|l|}{ Selected State Parks (2019 data) } \\
\hline Florida Caverns State Park & Jackson & 44,215 & $\$ 4.5$ million $\mathrm{DEI}^{\mathrm{b}}$ & $63^{c}$ & $\operatorname{FDEP}(2020)$ \\
\hline Ponce de Leon Springs State Park & Holmes & 69,073 & $\$ 6.3$ million DEI ${ }^{\mathrm{b}}$ & $89^{c}$ & FDEP (2020) \\
\hline Wakulla Springs State Park & Wakulla & 218,735 & $\$ 19.7$ million DEl ${ }^{\mathrm{b}}$ & $276^{c}$ & FDEP (2020) \\
\hline Grayton Beach State Park & Walton & 212,050 & $\$ 19.5$ million DEl ${ }^{b}$ & $274^{c}$ & FDEP (2020) \\
\hline Henderson Beach State Park & Okaloosa & 476,296 & $\$ 41.3$ million $\mathrm{DEI}{ }^{\mathrm{b}}$ & $578^{c}$ & $\operatorname{FDEP}(2020)$ \\
\hline St. Andrew State Park & Bay & 650,335 & $\$ 57$ million DEl ${ }^{b}$ & $798^{c}$ & FDEP (2020) \\
\hline Perdido Key State Park & Escambia & 215,257 & $\$ 18.4$ million DEl ${ }^{\mathrm{b}}$ & $258^{c}$ & FDEP (2020) \\
\hline $\begin{array}{l}\text { Recreation in the state parks listed above and the other state } \\
\text { parks in District } 1 \text { of the Florida state park system }{ }^{d}\end{array}$ & $-d$ & $3,638,530$ & $\$ 331$ million DEI ${ }^{b}$ & $4,637^{c}$ & FDEP (2020) \\
\hline \multicolumn{6}{|c|}{$\begin{array}{l}\text { a These indicators account for direct, indirect, and induced effects from visitor spending. Specifically, "economic output is a measure of the total estimated value } \\
\text { of the production of goods and services supported by NPS visitor spending. Economic output is the sum of all intermediate sales (business to business) and final } \\
\text { demand (sales to consumers and exports)... Jobs measure annualized full and part time jobs that are supported by NPS visitor spending" (p. 4, NPS 2020). } \\
\text { b This value focuses on direct impacts only, and it does not account for indirect and induced effects. Therefore, it is not directly comparable with the value } \\
\text { reported for the national parks. Direct economic impact (DEI) is defined as the amount of new dollars spent annually in a local economy by non-local park } \\
\text { visitors and park operations (FDEP 2020). } \\
\text { cIt is assumed that } 16 \text { jobs are supported per } \$ 1 \text { million in total expenditures in a given local area (FDEP 2020). It is not specified whether this value includes any } \\
\text { indirect or induced effects from the spending. } \\
\text { d Note that District } 1 \text { of the Florida state park system covers Florida Panhandle, and it slightly exceeds the area of the NWFWMD (see FDEP 2019). The estimates } \\
\text { reported in this row include the Edward Ball Wakulla Springs State Park. }\end{array}$} \\
\hline
\end{tabular}

Table 2. Visitors' willingness to pay (WTP) above the actual spending for recreational trips in the NWFWMD.

\begin{tabular}{|c|c|c|c|c|}
\hline Natural resource site and recreation type & County & Average WTP & $\begin{array}{l}\text { Aggregate } \\
\text { annual WTP }\end{array}$ & Reference \\
\hline \multicolumn{5}{|c|}{ Visitors' willingness to pay (WTP) above the actual spending for the trip } \\
\hline $\begin{array}{l}\text { Wakulla Springs, cavern and cave diving (if } \\
\text { allowed) }\end{array}$ & Wakulla & $\begin{array}{l}\$ 52-\$ 83 \text { per cave dive } \\
\$ 9 \text { per cavern dive (above the trip } \\
\text { expenditures) }\end{array}$ & $\$ 0.50$ million & Huth and Morgan (2011) \\
\hline Jackson Blue Springs, cave diving & Jackson & $\begin{array}{l}\$ 155 \text { per person per trip (above the } \\
\text { trip expenditures) }\end{array}$ & $\$ 0.58$ million & Morgan and Huth (2011) \\
\hline $\begin{array}{l}\text { Nature-based recreation at five key recreation } \\
\text { sites in the Apalachicola River Basin }{ }^{a}\end{array}$ & Gulf & $\begin{array}{l}\$ 74.18 \text { per visit-day (above the trip } \\
\text { expenditures) }\end{array}$ & \$484.56 million & Shreshta et al. (2007) \\
\hline
\end{tabular}


Table 3. Economic studies examining recreational benefits provided by water resources in the SRWMD.

\begin{tabular}{|c|c|c|c|c|c|}
\hline \multicolumn{6}{|c|}{ Contribution to the regional economy-economic impact analysis for selected state parks } \\
\hline Natural resource site and recreation type & County & $\begin{array}{l}\text { Annual } \\
\text { attendance }\end{array}$ & $\begin{array}{l}\text { Economic impact } \\
\text { indicator }\end{array}$ & $\begin{array}{l}\text { Total jobs } \\
\text { supported }\end{array}$ & Reference \\
\hline \multicolumn{6}{|l|}{ Selected state parks (2019 data) } \\
\hline Madison Blue Spring State Park & Madison & 24,558 & $\$ 2.2$ million $\mathrm{DEl}{ }^{\mathrm{b}}$ & $31^{\mathrm{a}}$ & $\operatorname{FDEP}(2020)$ \\
\hline Lafayette Blue Springs State Park & Lafayette & 17,671 & $\$ 1.8$ million $\mathrm{DEI}^{\mathrm{b}}$ & $26^{\mathrm{a}}$ & $\operatorname{FDEP}(2020)$ \\
\hline Suwannee River State Park & $\begin{array}{l}\text { Hamilton, Madison, } \\
\text { Suwannee }\end{array}$ & 45,465 & $\$ 4.2$ million $\mathrm{DEI}{ }^{\mathrm{b}}$ & $59^{a}$ & FDEP (2020) \\
\hline Wes Skiles Peacock Springs State Park & Suwannee & 11,118 & $\$ 1.0$ million $\mathrm{DEI}^{\mathrm{b}}$ & $14^{\mathrm{a}}$ & $\operatorname{FDEP}(2020)$ \\
\hline Troy Spring State Park & Lafayette & 6,450 & $\$ 0.6$ million $\mathrm{DEI}{ }^{\mathrm{b}}$ & $9^{a}$ & $\operatorname{FDEP}(2020)$ \\
\hline Ichetucknee Springs State Park & Columbia & 258,078 & $\$ 21.7$ million $\mathrm{DEI}{ }^{\mathrm{b}}$ & $304^{\mathrm{a}}$ & FDEP (2020) \\
\hline River Rise Preserve State Park & Alachua \& Columbia & 2,451 & $\$ 0.2$ million $\mathrm{DEI} \mathrm{I}^{\mathrm{b}}$ & $3^{a}$ & $\operatorname{FDEP}(2020)$ \\
\hline Gilchrist Blue Spring State Park & Gilchrist & 138,015 & $\$ 12.1$ million $\mathrm{DEI}{ }^{\mathrm{b}}$ & $169^{a}$ & $\operatorname{FDEP}(2020)$ \\
\hline Fanning Springs State Park & Levy & 180,423 & $\$ 15.7$ million DEI ${ }^{\mathrm{b}}$ & $220^{a}$ & FDEP (2020) \\
\hline Manatee Springs State Park & Levy & 256,631 & $\$ 22.6$ million $\mathrm{DEI}{ }^{\mathrm{b}}$ & $316^{\mathrm{a}}$ & $\operatorname{FDEP}(2020)$ \\
\hline $\begin{array}{l}\text { Recreation in the state parks listed above and the other } \\
\text { state parks in District } 2 \text { of the Florida state park system, } \\
\text { including both beaches and inland state parks }{ }^{c}\end{array}$ & $-c$ & $4,702,985$ & $\$ 420$ million DEI ${ }^{\mathrm{b}}$ & $5,878^{a}$ & $\operatorname{FDEP}(2020)$ \\
\hline \multicolumn{6}{|c|}{ Contribution to the regional economy-economic impact analysis for the sites including but not limited to state parks } \\
\hline Natural resource site and recreation type & County & $\begin{array}{l}\text { Annual } \\
\text { attendance }\end{array}$ & $\begin{array}{l}\text { Economic impact } \\
\text { indicator }\end{array}$ & $\begin{array}{l}\text { Total jobs } \\
\text { supported }\end{array}$ & Reference \\
\hline $\begin{array}{l}\text { Fifteen publicly and privately owned springs in the } \\
\text { Suwannee and Lower Santa Fe River Basins }\end{array}$ & Counties in SRWMD & $1,012,066$ & $\begin{array}{l}\text { Spending by local } \\
\text { and nonlocal } \\
\text { visitors: } \$ 84.19 \\
\text { million in Fiscal } \\
\text { Year } 2012-2013\end{array}$ & $1,160^{d}$ & $\begin{array}{l}\text { Borisova et } \\
\text { al. (2015) }\end{array}$ \\
\hline \multicolumn{6}{|c|}{$\begin{array}{l}\text { a It is assumed that } 16 \text { jobs are supported per } \$ 1 \text { million in total expenditures in local area (FDEP 2020). It is not specified whether this value includes any indirect } \\
\text { or induced effects from the spending. } \\
\text { b Direct economic impact (DEI) is defined as the amount of new dollars spent annually in a local economy by non-local park visitors and park operations (FDEP } \\
\text { 2020). This value does not account for indirect and induced effects of visitor spending. } \\
\text { c District } 2 \text { of the Florida state park system covers SRWMD (excluding Jefferson County and a part of Taylor County), as well as portions of SJRWMD and } \\
\text { SWFWMD (see FDEP 2019). The estimates reported in this row include the Ichetucknee Springs State Park. } \\
\text { d This value includes jobs supported by direct, indirect, and induced effects of visitor spending, and therefore, this value is not directly comparable with the } \\
\text { values reported for the state parks. }\end{array}$} \\
\hline
\end{tabular}

Table 4. Recreational benefits provided by water resources in the SRWMD: value beyond actual visitor spending.

\begin{tabular}{|l|l|l|l|}
\hline \begin{tabular}{|l} 
Visitors' willingness to pay (WTP) above the actual spending for the recreational trip \\
Natural resource site and recreation \\
type
\end{tabular} & \multicolumn{1}{|c|}{ County } & \multicolumn{1}{c|}{ Aggregate annual WTP } \\
\hline Fanning Springs State Park & Levy, Gilchrist & $\$ 6.33$ million (above the actual trip expenditures) & Wu et al. (2018) \\
\hline Ichetucknee Springs State Park & Columbia & $\$ 14.66$ million (above the actual trip expenditures) & Wu et al. (2018) \\
\hline Blue Springs (Gilchrist) & Gilchrist & $\$ 2.24$ million (above the actual trip expenditures) & Wu et al. (2018) \\
\hline Madison Blue Spring & Madison & $\$ 1.39$ million (above the actual trip expenditures) & Wu et al. (2018) \\
\hline
\end{tabular}


Table 5. Economic impact of water-based recreational in east Florida.

\begin{tabular}{|c|c|c|c|c|c|}
\hline \multicolumn{6}{|c|}{ Contribution to the regional economy-selected state and national parks } \\
\hline Natural resource site & County & $\begin{array}{c}\text { Annual } \\
\text { attendance }\end{array}$ & $\begin{array}{c}\text { Economic impact } \\
\text { indicator }\end{array}$ & $\begin{array}{l}\text { Total jobs } \\
\text { supported }\end{array}$ & Reference \\
\hline \multicolumn{6}{|l|}{ National parks (2019 data) } \\
\hline Timucuan Ecological \& Historic Preserve & Duval & 1.2 million & $\begin{array}{l}\text { \$100.5 million in } \\
\text { economic output }^{\mathrm{a}}\end{array}$ & $1,085^{\mathrm{a}}$ & NPS (2020) \\
\hline Canaveral National Seashore & Brevard & 1.9 million & $\begin{array}{l}\text { \$95.1 million in } \\
\text { economic output }{ }^{\mathrm{a}}\end{array}$ & $937^{\mathrm{a}}$ & NPS (2020) \\
\hline \multicolumn{6}{|l|}{ Selected state parks (2019 data) } \\
\hline Blue Spring State Park & Volusia & 561,219 & $\$ 48.8$ million $\mathrm{DEI}{ }^{\mathrm{b}}$ & $572^{c}$ & FDEP (2020) \\
\hline De Leon Springs State Park & Volusia & 243,285 & $\$ 21.4$ million DEI ${ }^{\mathrm{b}}$ & $300^{c}$ & FDEP (2020) \\
\hline Silver Springs State Park & Marion & 399,465 & $\$ 35.9$ million $\mathrm{DEI}^{\mathrm{b}}$ & $503^{c}$ & FDEP (2020) \\
\hline Wekiwa Springs State Park & $\begin{array}{l}\text { Seminole, } \\
\text { Orange, Lake }\end{array}$ & 431,982 & $\$ 38.2$ million $\mathrm{DEl} \mathrm{b}^{\mathrm{b}}$ & $535^{c}$ & FDEP (2020) \\
\hline Big Talbot Island State Park & Duval & 337,068 & $\$ 29$ million DEl ${ }^{b}$ & $407^{c}$ & FDEP (2020) \\
\hline Anastasia State Park & St. Johns & 967,489 & $\$ 83.9$ million $\mathrm{DE}^{\mathrm{b}}$ & $1,175^{c}$ & FDEP (2020) \\
\hline North Peninsula State Park & Volusia & 249,751 & $\$ 21.3$ million DEl ${ }^{b}$ & $299^{c}$ & FDEP (2020) \\
\hline Sebastian Inlet State Park & Brevard & 761,339 & $\$ 66.5$ million DEl ${ }^{\mathrm{b}}$ & $931^{c}$ & FDEP (2020) \\
\hline $\begin{array}{l}\text { Recreation in the state parks listed above and the other } \\
\text { state parks in District } 3 \text { of the Florida state park system, } \\
\text { including both beaches and inland state parks d }\end{array}$ & $\begin{array}{l}\text { Counties central- } \\
\text { eastern Floridad }\end{array}$ & $8,377,974$ & $\$ 716$ million $\mathrm{DEI}^{\mathrm{b}}$ & $10,319^{c}$ & FDEP (2020) \\
\hline \multicolumn{6}{|c|}{ Contribution to the regional economy-sites potentially including but not limited to state and national parks } \\
\hline Natural resource site & County & $\begin{array}{l}\text { Annual } \\
\text { attendance }\end{array}$ & $\begin{array}{l}\text { Economic Impact } \\
\text { Indicator }\end{array}$ & $\begin{array}{l}\text { Total job } \\
\text { supported }\end{array}$ & Reference \\
\hline Indian River Lagoon & $\begin{array}{l}\text { Volusia, Brevard, } \\
\text { Indian River, St. } \\
\text { Lucie, and Martin }\end{array}$ & $7,400,000$ & $\begin{array}{l}\text { Total annual } \\
\text { economic output } \\
\text { received in } 2014 \text { is } \\
\$ 7.6 \text { billion }\end{array}$ & $71,918^{\mathrm{e}}$ & $\begin{array}{l}\text { ECFRPC and } \\
\text { TCRPC (2016) }\end{array}$ \\
\hline \multicolumn{6}{|c|}{$\begin{array}{l}\text { aThese indicators account for direct, indirect, and induced effects from the visitor spending. Specifically, "economic output is a measure of the total estimated } \\
\text { value of the production of goods and services supported by NPS visitor spending. Economic output is the sum of all intermediate sales (business to business) } \\
\text { and final demand (sales to consumers and exports) ... Jobs measure annualized full and part time jobs that are supported by NPS visitor spending" (p. 4, NPS } \\
2020 \text { ). } \\
\text { b This value focuses on direct impacts only, and it does not account for indirect and induced effects. Therefore, it is not directly comparable with the value } \\
\text { reported for the national parks. Direct economic impact (DEI) is defined as the amount of new dollars spent annually in a local economy by non-local park } \\
\text { visitors and park operations (FDEP 2020). } \\
\text { cIt is assumed that } 16 \text { jobs are supported per } \$ 1 \text { million in total expenditures in a given local area (FDEP 2020). It is not specified whether this value includes any } \\
\text { indirect or induced effects from the spending. } \\
{ }^{d} \text { Note that District } 2 \text { of the Florida state park system also covers part of the SJRWMD. For the map of the districts, see FDEP 2018. } \\
\text { e This value includes direct, indirect, and induced effects, and therefore, it is comparable with metrics reported for the national parks in NPS (2020). }\end{array}$} \\
\hline
\end{tabular}

Table 6. Visitors' willingness to pay (WTP) above the actual spending for the recreational trip.

\begin{tabular}{|c|c|c|c|}
\hline \multicolumn{4}{|c|}{ Visitors' willingness to pay (WTP) above the actual spending for the recreational trip } \\
\hline Natural resource site & County & Economic Estimate & Reference \\
\hline St. Johns River Basin & Counties in SJRWMD & $\begin{array}{l}\text { Estimated value derived by the visitors to inland water } \\
\text { recreation sites is } \$ 208.9 \text { million per year (in addition to } \\
\text { the actual expenditure for the recreational trips). }\end{array}$ & Ehrlich et al. (2017) \\
\hline Springs in Ocala National Forest & $\begin{array}{l}\text { Marion, Lake, Putnam, } \\
\text { and Seminole }\end{array}$ & $\begin{array}{l}\text { The willingness to pay: } \$ 1.0 \text { to } \$ 2.5 \text { million per year } \\
\text { (depending on level of facilities provided at the site) in } \\
\text { addition to the actual expenditure for the recreational } \\
\text { trips }\end{array}$ & Shreshta et al. (2002) \\
\hline
\end{tabular}


Table 7. Economic studies focusing on amenity values provided by water resources in east Florida.

\begin{tabular}{|c|c|c|c|}
\hline \multicolumn{4}{|c|}{ Amenity values provided by water resources in east Florida } \\
\hline Area & County & Economic Value & Reference \\
\hline St. Johns River & Duval, Clay, Putnam, and St. Johns & $\begin{array}{l}\text { St. Johns River water quality improvements can } \\
\text { increase the value of properties along the river by } \\
\$ 346.1 \text { million }\end{array}$ & Seidel et al. (2015) \\
\hline Lakes in urban Orange County & Orange & $\begin{array}{l}\text { An increase in transparency depth by one foot } \\
\text { results in an increase in average home sale price by } \\
\text { about } 1.2 \% \text { (or } \$ 6,900) \text { for lakefront properties, and } \\
0.3 \%(\$ 880) \text { for non-lakefront properties }\end{array}$ & Walsh et al. (2010) \\
\hline
\end{tabular}

Table 8. Economic studies focusing on the value of water quality Improvements in east Florida.

\begin{tabular}{|l|l|l|l|l|}
\hline \multicolumn{1}{|c|}{ Willingness to pay for tap and well water quality improvements } & \multicolumn{1}{|c|}{ Economic Value } \\
\hline Aap water supplied to Jacksonville & County & Duval & $\begin{array}{l}\text { In total, customers of the Jacksonville Electrical Authority (JEA) are } \\
\text { willing to pay \$746,400 monthly for water quality improvements } \\
(\$ 6.22 \text { per person per month) }\end{array}$ & Chatterjee et al. (2017) \\
\hline $\begin{array}{l}\text { Well water in rural areas of Lake } \\
\text { County }\end{array}$ & Lake & $\begin{array}{l}\text { When total nitrate and nitrite concentration in well water exceeded } \\
\text { the drinking water quality standards, the reduction in the home sale } \\
\text { price was } 7 \text { to } 15 \text { percent. }\end{array}$ & Guignet et al. (2016) \\
\hline
\end{tabular}

Table 9. Economic studies examining recreational benefits provided by water resources in the SWFWMD.

\begin{tabular}{|c|c|c|c|c|c|}
\hline \multicolumn{6}{|c|}{ Contribution to the regional economy-economic impact analysis } \\
\hline Natural resource site and recreation type & County & $\begin{array}{c}\text { Annual } \\
\text { attendance }\end{array}$ & $\begin{array}{l}\text { Economic impact } \\
\text { Indicator }\end{array}$ & $\begin{array}{l}\text { Total jobs } \\
\text { supported }\end{array}$ & Reference \\
\hline \multicolumn{6}{|l|}{ Selected state parks ${ }^{a}$} \\
\hline Rainbow Springs State Park & Marion & 353,764 & $\$ 31.1$ million DEl ${ }^{\mathrm{b}}$ & $436^{c}$ & $\operatorname{FDEP}(2020)$ \\
\hline Ellie Schiller Homosassa Springs Wildlife State Park & Citrus & 228,044 & $\$ 21.4$ million $\mathrm{DEI}{ }^{\mathrm{b}}$ & $300^{c}$ & $\operatorname{FDEP}(2020)$ \\
\hline Weeki Wachee Springs State Park & Hernando & 284,470 & $\$ 19.3$ million $\mathrm{DEI}^{\mathrm{b}}$ & $410^{c}$ & $\operatorname{FDEP}(2020)$ \\
\hline Werner-Boyce Salt Springs State Park & Pasco & 27,001 & $\$ 2.5$ million $\mathrm{DEI}^{\mathrm{b}}$ & $36^{c}$ & $\operatorname{FDEP}(2020)$ \\
\hline Honeymoon Island State Park & Pinellas & $1,610,871$ & $\$ 140.3$ million DEI ${ }^{\mathrm{b}}$ & $1,965^{c}$ & FDEP (2020) \\
\hline Caladesi Island State Park & Pinellas & 288,445 & $\$ 25.5$ million $\mathrm{DEI}{ }^{\mathrm{b}}$ & $357^{c}$ & FDEP (2020) \\
\hline Anclote Key State Park & Pinellas & 226,846 & $\$ 19.5$ million DEl $^{\mathrm{b}}$ & $274^{c}$ & $\operatorname{FDEP}(2020)$ \\
\hline \multicolumn{6}{|c|}{$\begin{array}{l}\text { a Economic impact estimates for the other state parks located in the SWFWMD are available in FDEP (2020). Note that the districts defined by the Florida state } \\
\text { park system do not coincide with the SWFWMD boundaries. As a result, SWFWMD is split between Districts } 2,3 \text {, and } 4 \text {. } \\
\text { b Direct economic impact (DEI) is defined as the amount of new dollars spent annually in a local economy by non-local park visitors and park operations (FDEP } \\
\text { 2020). This value does not account for indirect and induced effects and therefore is not directly comparable with the value reported for the national park. } \\
\text { c It is assumed that } 16 \text { jobs are supported per } \$ 1 \text { million in total expenditures in a given local area (FDEP 2020). It is not specified whether this value includes any } \\
\text { indirect or induced effects from the spending. }\end{array}$} \\
\hline
\end{tabular}


Table 10. Economic value of services provided by water resources in the SFWMD.

\begin{tabular}{|c|c|c|c|c|c|}
\hline \multicolumn{6}{|c|}{ Contribution to the regional economy-economic impact analysis } \\
\hline Natural resource site and recreation type & County & $\begin{array}{l}\text { Annual } \\
\text { attendance }\end{array}$ & $\begin{array}{l}\text { Economic impact } \\
\text { indicator }\end{array}$ & $\begin{array}{l}\text { Total jobs } \\
\text { supported }\end{array}$ & Reference \\
\hline \multicolumn{6}{|l|}{ National parks (2019 data) } \\
\hline Big Cypress National Preserve & Collier & $1,007,471$ & $\begin{array}{l}\text { \$117.1 million } \\
\text { economic output }\end{array}$ & $1,080^{\mathrm{a}}$ & NPS (2020) \\
\hline Biscayne National Park & Miami-Dade & 708,552 & $\begin{array}{l}\text { \$64.7 million } \\
\text { economic output }{ }^{a}\end{array}$ & $606^{\mathrm{a}}$ & NPS (2020) \\
\hline Everglades National Park & Miami-Dade & $1,118,300$ & $\begin{array}{l}\$ 164.9 \text { million } \\
\text { economic output }{ }^{\text {a }}\end{array}$ & $1,508^{\mathrm{a}}$ & NPS (2020) \\
\hline \multicolumn{6}{|l|}{ Selected state parks (2019 data) } \\
\hline Delnor-Wiggins Pass State Park & Collier & 539,633 & $\$ 46.9$ million DEI ${ }^{\mathrm{b}}$ & $657^{c}$ & FDEP (2020) \\
\hline Gasparilla Island State Park & Lee & 281,241 & $\$ 24.4$ million DEI ${ }^{\mathrm{b}}$ & $341^{c}$ & FDEP (2020) \\
\hline Lovers Key State Park & Lee & 806,978 & $\$ 69.7$ million $\mathrm{DEI}^{\mathrm{b}}$ & $976^{c}$ & FDEP (2020) \\
\hline Bahia Honda State Park & Monroe & 438,179 & $\$ 40.6$ million $\mathrm{DEI}{ }^{\mathrm{b}}$ & $568^{c}$ & $\operatorname{FDEP}(2020)$ \\
\hline Bill Baggs Cape Florida State Park & Miami-Dade & 675,000 & $\$ 58.9$ million $\mathrm{DEI}{ }^{\mathrm{b}}$ & $824^{c}$ & $\operatorname{FDEP}(2020)$ \\
\hline John Pennekamp Coral Reef State Park & Monroe & 569,194 & $\$ 50.3$ million DEI $^{\mathrm{b}}$ & $704^{c}$ & FDEP (2020) \\
\hline Dr. Von D. Mizell-Eula Johnson State Park & Broward & 340,778 & $\$ 30.3$ million DEl ${ }^{b}$ & $424^{c}$ & $\operatorname{FDEP}(2020)$ \\
\hline Wekiwa Springs State Park & Orange & 431,982 & $\$ 38.2$ million $\mathrm{DEI}{ }^{\mathrm{b}}$ & $535^{c}$ & $\operatorname{FDEP}(2020)$ \\
\hline $\begin{array}{l}\text { All state parks in District } 4 \text { of the Florida state park system, } \\
\mathrm{d} \text { including both beaches and inland state parks }\end{array}$ & $-d$ & $6,572,231$ & $\$ 585$ million DEI ${ }^{\mathrm{b}}$ & $7,038^{c}$ & $\operatorname{FDEP}(2020)$ \\
\hline $\begin{array}{l}\text { All state parks in District } 5 \text { of the Florida state park system, e } \\
\text { including both beaches and inland state parks }\end{array}$ & $-e$ & $6,154,633$ & $\$ 546$ million DEI $^{\mathrm{b}}$ & $7,649^{c}$ & FDEP (2020) \\
\hline \multicolumn{6}{|c|}{$\begin{array}{l}\text { "These indicators account for direct, indirect, and induced effects from the visitor spending. Specifically, "economic output is a measure of the total estimated } \\
\text { value of the production of goods and services supported by NPS visitor spending. Economic output is the sum of all intermediate sales (business to business) } \\
\text { and final demand (sales to consumers and exports) ... Jobs measure annualized full and part time jobs that are supported by NPS visitor spending" (p. 4, NPS } \\
2020 \text { ). } \\
\text { b This value focuses on direct impacts only, and it does not account for indirect and induced effects. Therefore, it is not directly comparable with the value } \\
\text { reported for the national parks. Direct economic impact (DEI) is defined as the amount of new dollars spent annually in a local economy by non-local park } \\
\text { visitors and park operations (FDEP 2020). } \\
\text { cIt is assumed that } 16 \text { jobs are supported per } \$ 1 \text { million in total expenditures in a given local area (FDEP 2020). It is not specified whether this value includes any } \\
\text { indirect or induced effects from the spending. } \\
\text { d District } 4 \text { of the Florida state park system covers parts of the SWFWMD and SFWMD. For the map of the districts, see FDEP } 2018 \text {. } \\
\text { e District } 5 \text { of the Florida state park system covers part of the SFWMD. For the map of the districts, see FDEP } 2018 \text {. }\end{array}$} \\
\hline
\end{tabular}

Table 11. Examples of amenity values provided by water resources.

\begin{tabular}{|l|l|l|l|l|}
\hline \multicolumn{1}{|c|}{ Amenity values provided by water resources in south Florida } & \multicolumn{1}{c|}{ Economic Value } \\
\hline $\begin{array}{l}\text { St. Lucie River Estuary and Loxahatchee } \\
\text { Estuary }\end{array}$ & Martin & $\begin{array}{l}\text { An increase in average water clarity by 1\% results } \\
\$ 36,070 \text { increase in the property sale price, on average. }\end{array}$ & Bin and Czajkowski (2013) \\
\hline $\begin{array}{l}\text { St. Lucie Estuary and Loxahatchee Estuary } \\
\text { Martin }\end{array}$ & $\begin{array}{l}\text { A 1\% increase in water quality grade is valued at \$2,614 } \\
\text { by the property buyers on average }\end{array}$ & Bin et al (2017) \\
\hline
\end{tabular}

Table 12. Examples of the values of supporting and regulating ecosystem services provided by water resources.

\begin{tabular}{|l|l|l|}
\hline \multicolumn{1}{|c|}{ Willingness to pay for supporting and regulating ecosystem services } & \multicolumn{1}{c|}{ Economic Value } \\
\hline Restoring the greater Everglades & $\begin{array}{l}\text { Average household WTP is } \$ 81 \text { per year. Extrapolation of these } \\
\text { results to the total Florida population shows that the WTP is \$468 } \\
\text { million annually, or \$4.7 billion over a ten-year period. }\end{array}$ & Milon and Scrogin (2006) \\
\hline $\begin{array}{l}\text { Ecosystem services provided by mangroves in } \\
\text { the Everglades National Park }\end{array}$ & $\begin{array}{l}\text { The total cost of preserving the natural habitat in the Everglades is } \\
\text { calculated to be } \$ 18.3 \text { billion. }\end{array}$ & Alongi (2012) \\
\hline
\end{tabular}

